International Journal of Fashion Design, Technology and Education

Vol. 1, No. 3, November 2008, 113-123

\title{
Exploring Learning Experience in Textile and Apparel Management: Study Abroad in El Salvador
}

\author{
Jung Ha-Brookshire \\ Department of Textile and Apparel Management, University of Missouri, Columbia, USA \\ (Received 29 July 2008; final version received 2 October 2008)
}

Global economy has fundamentally changed the nature of business as well as the mission of higher education. Professional academic programmes, such as textiles and apparel, are ultimately responsible for preparing students to be industry-ready and, thus, various curricula have been developed to address this new need of the industry (Fair et al. Clothing and Textiles Research Journal 1990;8(2):29-37). Particularly, experiential learning has shown to be effective at student learning; international experience learning has become popular in the education literature. While most previous research has focused on the process and outcomes of new curricula, the study analysed students' journals from a short-term study aboard curriculum to capture how students grasp, conceptualise, reflect on and experiment with new experiences under an experiential learning theory framework (Kolb, Experiential learning: experience as the source of learning and development; 1984). Eight themes emerged; two from each of the four learning modes. The findings are discussed and the study is concluded with contributions, implications and future research opportunities.

Keywords: experiential learning; study abroad; higher education; globalisation; textiles and apparel

\section{Introduction}

Global economy has fundamentally changed the nature of business activities in the textile and apparel industry (Dicken, 2004; Dickerson, 1999; Ha-Brookshire and Dyer, 2008; Kunz and Garner, 2007). The force of globalization has also made U.S. higher education adopt international components in textile and apparel businesses and management programs. The popularity of textbooks in the area of the global textile and apparel industry, such as Textiles and Apparel in the Global Economy (Dickerson, 1999), Global Shift: Reshaping the Global Economic Map in the $21^{\text {st }}$ Century (Dicken, 2004), Going Global: The Textile and Apparel Industry (Kunz and Garner, 2007), and World Wise: What to Know Before You
Go (Denslow, 20006) clearly supports for this trend.

In the past two decades in U.S. higher education, the move from traditional, passive teaching modes in classes using textbooks to experiential, active learning in various settings has been encouraged (Frontczak, 1998). Textiles and apparel programs were not an exception to this trend. There has been an apparent consensus on the importance of internships among retailing, merchandising, and apparel educators (Jennings-Rentenaar et al., 2008). Experiential learning refers to a teaching method that allows students to become active participants in their own education through experience (Kolb, 1984; Wynd, 1989). Experiential learning is believed to complement classroom learning by helping increase the learner's motivation and long- 
term retention of knowledge (Coleman, 1976). Injected reality in experiential learning also enhances students' ability to apply and integrate what they have learned in classroom (O'Hara and Shaffer, 1995). Much research is available on how experiential learning helps students' overall learning and how it takes place (Chapman et al., 1995; Coleman, 1976; Gaidis and Andrews, 1990; Joplin, 1995; Kraft and Kielsmeier, 1995; O'Hara and Shaffer, 1995; Parilla and Hesser, 1998; Sakofs, 1995; Warren et al., 1995; Wynd, 1989).

Most of the past research on experiential learning, however, was mainly designed to help educators who wished to develop new curricula or courses; thus, the findings tended to be procedure- and outcome-oriented in experimental learning (e.g., Festervand and Tillery, 2001; Helms et al., 2003; Tchaich et al., 2005; Toncar and Cudmore, 2000). Although these studies provided important insights, little is known about how students experience and gain new knowledge from that experience. A close understanding of student learning is particularly crucial in textile and apparel education in which international perspective is critical due to the highly globalized business nature. To address this gap, the study aimed to explore a richer, deeper understanding of students' experiential learning from a learner's perspective, through interpreting student journals from a short-term study abroad program.

This paper first presents an overview of Kolb's (1984) experiential learning theory, four learning modes, and the concept of learning space, followed by international experiential learning in textile and apparel academic programs in the United States. Next, the study's research question and methodology are discussed, including the detailed information on the Study Aboard in El Salvador curriculum and participating students' profile. The study findings follow, and, finally, the paper concludes with the contributions and implications of the study findings, and future research opportunities.

\section{Literature review}

\subsection{Experiential learning theory}

Emphasis on experiential learning is not new. The evidence of experiential, participatory, active learning traces back to Socrates who preferred teaching by asking questions to his students (Frontczak, 1998). Although there have been numerous attempts to formally define experiential learning, Kolb's (1984) experiential learning theory (ELT) has been widely accepted (Chapman et al., 1995; Joplin, 1995; Sakofs, 1995). ELT is considered a holistic theory of the learning process incorporating individual's different learning styles, that is, the manner in which the learner acquires, retains, and recalls the information (Felder and Henriques, 1995; Fontczak, 1998; Kolb and Kolb, 2005). In ELT, Kolb (1984, p. 41) defined experiential learning as "the process whereby knowledge is created through the transformation of experience" and explained that knowledge is formulated by both grasping and transforming experience. Concrete experiences and abstract conceptualization are the modes related to grasping experience, and reflective observation and active experimentation are those related to transforming experience. Thus, experiential learning is a complex process of constructing knowledge through four different learning modes that are creatively evaluated and selected to meet specific knowledge demands. When this procedure becomes a cycle or spiral with continuous feedback, it is considered an ideal experiential learning process in which the learner would be able to "touch all the bases-experiencing, reflecting, thinking, and acting" (Kolb and Kolb, 2005, p. 194).

\subsection{Four learning modes}


According to ELT, there are four different learning modes. Certain learning modes can be more dominant than others, depending upon the learner's learning style and learning demands (Kadolph, 2005; Kolb and Kolb, 2005). The first learning mode, concrete experience, is a fundamental basis for new knowledge in experiential learning. Concrete experience is grasped by directly observing or participating in particular events. Thus, actual experience is a must in any learning. The second learning mode, reflective observation, takes place when the learner steps back, ponders, questions, and evaluates his or her own experiences. In reflective observation, the learner's feelings, reactions, and emotions are important for learning. The third learning mode, abstract conceptualization, helps the learner form tentative hypotheses for generalizations using relevant and existing concepts or theories based on his or her own experience. Thus, it is important for the learner to be able to relate the experience with the relevant theories or concepts previously learned. Finally, active experimentation is the fourth learning mode, and it happens when the learner is able to test, apply, and act on what has been learned from the experience in new situations. Thus, active experimentation results in a new experience from the previous experience, leading to a new learning cycle.

\subsection{Learning space}

In addition to the process of experiential learning, the importance of learning space has been discussed in the literature. Learning space researchers suggest that learning is a transaction between the learner and the environment which he or she experiences subjectively (Marrow, 1969; Kolb and Kolb, 2005). Specifically, Bronfrenbrenner (1979) explained four different levels of learning space influencing one's learning. Micro-system refers to the learner's immediate setting, such as a course or classroom, while meso-system is other concurrent settings in the learner's life, such as other classes, the dorm, or family. The exo-system includes the formal and informal social structures impacting micro- and meso-systems, such as institutional policies and campus culture. Finally, the macrosystem refers to the overarching institutional patterns and values of the wider culture affecting all other systems, such as the cultural values favoring quantitative results to qualitative outcomes. With a special focus on the learner's environment on the learning process, situated learning theory pays particular attention to the social aspects of the environment, as represented through these four systems. Situated learning theorists suggest that situations in which the learner is placed ultimately influence the outcome of his or her learning; thus, the characteristics of a social environment are significant factors for one's learning (Lave and Wenger, 1991; Marrow, 1969).

\subsection{International experiential learning in} U.S. textiles and apparel programs

As experiential learning theory has offered new ways to approach teaching and has promised unprecedented success in education and professional development; numerous educators and researchers have implemented ELT in curricula (Gosen and Washbush, 2004; Tchaicha and Davis, 2005). At the same time, global competition and collaboration have intensified; business schools across the United States have incorporated experiential learning with international components (Helms et al., 2003). Consequently, international study abroad programs or international experiential learning curricular have been prolific. These programs have claimed that international experiential learning opportunities offer a variety of educational benefits, including more open-minded 
attitudes, a broader frame of reference, and a better understanding of travel, history, geography, culture, people, and international business practices (Festervand and Tillery, 2001; Helms et al., 2003; Toncar and Cudmore, 2000).

Despite the plethora of international experiential learning studies in the business literature, similar studies in the textile and apparel literature are not easy to find. The lack of research in international experiential learning in textile and apparel academic programs is surprising when considering the extent of global aspects in the textile and apparel industry. Indeed, the textile and apparel industry is the most globalized of all (Dicken, 2003) and the majority of business activities of U.S. textile and apparel companies are significantly dependent on foreign markets (Ha-Brookshire and Dyer, 2008). Thus, international components in textile and apparel academic programs are fundamental and a deep appreciation on how textiles and apparel students learn these international contexts is critical to help students be 'global-society ready' upon graduation. To address this gap, using ELT as a theoretical framework, the study aimed to obtain an intimate, deep understanding of how students grasp and transform experience in creating new knowledge in an unfamiliar, foreign learning environment from a student's perspective.

\section{Method}

To obtain a richer, deeper understanding of students' experiential learning, the study analyzed and interpreted the texts of student journals from a short-term study abroad program in El Salvador led by the author, a faculty member of the Department of Textile and Apparel Management at the University of Missouri. Interpretive research is particularly appropriate when the researcher aims to uncover a deeper dimension of the ways in which participants subjectively experience their world (Hultgren, 1989). An interpretive approach also helps the researcher understand participants' world by rich descriptions of their experiences and reveals depth realities that could be far different from surface appearances (Merriam, 1998). These rich descriptions are communicated though language in human society; without these descriptions, it is almost impossible for others to grasp the nature and significance of a phenomenon in the way that one experiences them (Gadamer, 1975; van Manen, 1990). Therefore, written text is one of the commonly used data sets in interpretive research to grasp the essence of a phenomenon and reveal the meanings of participant experiences (Mason, 1996; Merriam, 1998).

\subsection{Study Abroad in El Salvador}

El Salvador is located in Central America bordering the North Pacific Ocean between Guatemala and Honduras. The country is currently undergoing both rapid industrialization and population growth (The World Factbook, 2008). Particularly, in the past few decades, El Salvador has been one of the key buyers and suppliers for the U.S. textile and apparel industry, and the trade between El Salvador and the United States has been accelerated under the Central American Free Trade Agreement (Kunz and Garner, 2007). El Salvador has adopted the U.S. dollar as its currency since 2001, attracting foreign investment, specifically from the United States (The World Factbook, 2008). Thus, El Salvador is believed to have made and continues to make important and significant contributions to the U.S. textile and apparel industry.

The Study Abroad in El Salvador took place in May 2008. It was an intensive, week-long program, specifically focused on the Salvadorian textile and apparel industry 
and culture. The program offered three credit hours to participating students. To receive the full three credits, students were required complete several assignments. First, students had to attend two predeparture meetings. It took two hours for each meeting; the first meeting took place in February and the second one in April 2008. The first meeting was designed to get to know each other and to provide an overview of the program details. Details on passport, immunization, and general health and safety issues were discussed. The second meeting was to follow up the process of students' trip preparation, including the status of necessary travel documents and immunization. Students were also asked to read Chapter 21, Travel, from World Wise: What to Know Before You Go by Denslow (2006) before packing. The chapter provided important insights into preparation for international trips, including packing.

Second, students were required to submit individual research papers on the Salvadorian culture, politics, economy, and history. This research paper had a limitation of two pages, single spaced. In addition to the pre-departure meetings and research paper, individual journals were required. To complete journals, students had to record and document what they had seen, touched, smelled, heard, and felt during the trip. To complete the journal assignment, this raw experience was then used as a basis for reflection and reevaluation of their experience. The individual journals were due two weeks after the trip ended.

The Study Abroad in El Salvador was hosted by Promoviendo la Inversión en El Salvador (PROESA), that is, the National Investment Promotion Agency of El Salvador. Currently, PROESA is the only government agency dedicated to promoting foreign investment in El Salvador (PROESA, 2008). Program activities included discussions with a senior investment advisor at PROESA, a senior commercial specialist at the Embassy of the United States of America, and a representative of Camara de la Industria Textil y de la Confeccion de El Salvador (CAMTEX), a textile industry association. The program also offered tours with the owners or senior managers from several textile and apparel manufacturing factories in El Salvador, including Duraflex, Partex, and Industrias St. Jack's. Duraflex employs 1300 workers in El Salvador and has been acquired by Hanesbrands, Inc., which is headquartered in Winston-Salem, North Carolina, in 2007 (Business Wire, 2007). Partex is a sewing plant whose main buyers are Under Amor, National Football League, and Reebok. Industrias St. Jack's is one of the few Salvadorian brands with a complete vertical supply chain system in Central America; they conduct their own market research, product development, production, marketing, and distribution. The program also included multiple visits to local places for cultural immersion, such as Mayan ruins, museums, downtown market areas, large shopping malls, and local restaurants. The full itinerary is available in Table 1.

\subsection{Data collection and analysis}

The study's main data, student journals, were submitted via email. Electronic copies of journals included photos and texts. The journal assignment had no limitation on the length so as not to constrain the degree of student reflections. On average, each journal was seven- to eight-pages long in single space. In total, 18 students participated in Study Abroad in El Salvador and all of them agreed to share their journals for the research. 17 out of 18 were undergraduate students, ranging from sophomore to senior, and one was graduate student. All eighteen students were pursuing Textile and Apparel Management as their major or minor. Participating 
students who indicated their GPA scores had an overall average of 2.4 or above. Half of the participating students admitted that they had little knowledge on El Salvador. Only four students had had international trip experience prior to this program. Table 2 illustrates the participating students' demographic/biographic information.

A review of student journals indicated repeating ideas, suggesting information saturation (Mason, 1996). Multiple cycles of interpretation were conducted, using an experiential learning theory framework. First, the entire journal text was read in its entirety to obtain a holistic view of the total text. Then, each student's text was compared with the rest of the students' texts for similarities and differences. This procedure was repeated, allowing reflection on the previously interpreted text in light of newly developed understandings (Dutton and Dukerich, 1991; Thompson, 1997). As a result, a total of eight themes under the four learning mode categories emerged across the texts. To ensure validity of the interpretation, the final analysis was shared with all participating students. Each student was asked to review and respond to the content of the analysis and confirm whether the analysis correctly reflected their experience. This participation confirmation enhances the validity of the interpretive analysis (Nelson et al., 2002). None of the students expressed any disagreement on the analysis.

\section{Findings/Interpretation}

\subsection{Grasping experience through concrete experience}

Students saw, heard, smelled, tasted, and felt El Salvador throughout the trip. Many business strategies were told by multiple presenters from either factories or government agencies. Numerous sceneries and museums were visited and histories were read. However, the study data suggested that students seemed to grasp the most experience by interpreting the environment to which they were exposed. In other words, this environment was new, different from home, and incomprehensible to them, and students had to develop their own interpretation of the environment to understand the situation in which they were. Two distinctive themes emerged in the students' new experiences: (1) Americans stick out like a sore thumb; and (2) chaos means danger.

Americans stick out like a sore thumb. For most students, Study Abroad in El Salvador was the first international travel to non-white regions or cultures. They almost never had been in the environment in which young white females stood out as a minority. Being in El Salvador made white female students very uncomfortable. Overwhelmingly, students expressed that they felt 'odd' and 'out of place' as white, blonde, and U.S. American . Interestingly, this oddness and awkwardness was described with negative terms, such as 'clueless', 'obnoxious,' or 'sore thumb.' It is now known why students concluded that being white or being different was causing negative scenes in El Salvador.

For example, upon arrival at the San Salvador airport, which is the only international airport in El Salvador, Laura's luggage was randomly selected for security check by the Salvadorian police. Her luggage was chosen not because she was a U.S. American, but because she happened to be standing where the random selection was made. Despite having been informed of this selection process prior to arrival, getting her luggage inspected by the Salvadorian police, while being stared by hundreds of local

\footnotetext{
${ }^{1}$ The study distinguishes U.S. Americans from the term Americans. Americans consist of North, Central, and South Americans. Salvadorians are Central Americans.
} 
people in the hot, crowded, humid airport, made her feel like a 'clueless' American:

Laura: I was feeling especially sorry for myself at this point as the airport was hot and it was frustrating to try to communicate in a country where English is not the main language. I was feeling culture shock as my bags were searched and I stood watching, dripping with sweat, being stared at by locals most likely because I was clearly a clueless American.

Pam also thought her white skin, blonde hair, and a large charter bus that she was riding in represented U.S. Americans. Although "starting at others" in some cultures could mean curiosity, she concluded that local Salvadorians were staring at her because she was a member of the 'obnoxious' group to which she belonged. Similarly, Sally also agreed that her group was 'a sore thumb' in a place to which they did not belong:

Pam: I felt like everyone was staring at us and I couldn't figure out because it was our coloring or because we were getting off a really obnoxious bus. I think we definitely looked like Americans because we had really different ethnicities with us. I felt really out of place being super pale and blonde.

Sally: I have to admit that it was one of the weirdest and most insecure feelings I have ever had. In downtown San Salvador, we walked the streets and went to places in which all eyes were on us, the tourist. Americans stick out like a sore thumb.

Chaos means danger. Next to the airport experience in El Salvador, students unanimously agreed that walking down the streets and markets in downtown San Salvador was the most shocking, yet the most effective way to learn about the Salvadorian culture. Downtown San Salvador was full of activities and filled with street merchants, shoppers, homeless people, loud music, and overwhelming stench. Most of the music playing was in Spanish, yet some U.S. American music was also played. Many merchants were yelling and shouting to attract local shoppers and to announce special deals. Literally, all five senses were stimulated and amplified. For students, the loudness, odd smells, and large crowd seemed chaotic, and chaos meant lack of order, and ultimately, danger to their safety. Although Mary admitted that it was a once-in-a-lifetime experience, it was a very intimidating and uncomfortable event for her. Similarly, Anita immediately linked chaos and concerns about her safety upon arrival in this new environment:

Mary: Perhaps that most informative and exciting way of learning about the El Salvadoran culture was by walking the streets and markets of San Salvador. Although I was very nervous, it was such a once in a lifetime experience. Our group stood out so much among the people that it was a little intimidating. A lot of the vendors were yelling, pointing, and staring at us, which made a lot of people (including myself) uncomfortable.

Anita: When we reached the downtown area, I began to get a little bit nervous about my safety. There was a stench in the air and trash and filth all over the streets. Music was blaring from marketplace. Vendors were lined up on the left and right selling clothing, fresh produce, movies, CD's, cell phones, etc.

For Annie, it was more than an uncomfortable or inconvenient experience. The visceral experience of walking through the downtown San Salvador literally made 
her dizzy, anxious, and nauseous, and eventually frightened:

Annie: Today was my first day experiencing the true culture of $\mathrm{El}$ Salvador. My head is still spinning from everything I have seen. I am very anxious and even nauseous. The poverty is unimaginable. Tons of street vendors, people sleeping in the streets. I will do my best to put into words all of the wonderful, shocking and sometimes frightening things I experienced today.

\subsection{Grasping experience through abstract conceptualization}

Most students on this program had a good amount of knowledge about the global textiles and apparel industry. Prior to the trip, each student has taken, on average, seven courses in textile and apparel management, such as Textiles, Global Sourcing, Introduction to the Textile and Apparel Industry, and Softgoods Retailing. It was reasonable to conclude that students had sufficient knowledge to compare what they had learned in class and what they were experiencing in El Salvador. Interestingly, according to students, theories and concepts from textbooks do not teach them 'much,' nor become 'cool' until they actually experience it. Without this live, cool knowledge, their learning would be static and similar to other students who have not experienced [what? the theories and concepts in action?]. This seemed to provide competitive advantages over others. Two themes surfaced on conceptualizing experience: (1) live, cool knowledge that I love; and (2) live, cool knowledge as competitive advantage.

Live, cool knowledge that I love. Throughout the study data, it was expressed that students' knowledge from previous learning finally becomes alive when they actually see it. Kathy admitted that textbooks and theories had not been totally effective in her learning until she actually visited a textile plant and saw all the processes:

Kathy: Meeting with Duraflex [a textile plant] I felt like I learned so much and finally got to see firsthand what we learn about and discuss in class and it is not just in books and theory anymore. Next going to Partex [an apparel manufacturing plan] to see sewing and finished products was cool to relate the processes we put together for our sourcing projects and the actual plans when developing a product such as the samples and directions required by the companies for putting together a certain garment.

Particularly, in Kris' case, she actively sought the real examples of lean strategy as performed in a real company. It was an excellent way for her to solidify previous learning by seeing and touching real materials, such as the color-coded labels of fabric rolls showing different quality levels, and the wall signs of inventory levels indicating the amount of raw materials that would be fed into the next operation:

Kris: This was the coolest tour I've ever been on! Or the one that I learned the most on! I truly enjoyed listening to the CEO speaking about the company and how much they are focused on a "lean" strategy. This basically means they listen to the individual and collective ideas of their employees to make everyone's work-day easier and more efficient, all the while making the employees feel more involved and important. Everything from labeling the rolls of fabric with strips of colored fabric instead of just a little piece of paper that can be lost easily. The company used many of these "lean" strategies! 
It appeared that once knowledge becomes live and cool, students' interests in learning becomes more intensified. For Pam, it was beyond cool to learn about the textile manufacturing process. She 'loved' them; she even suggested a better way to learn this topic and even wanted to learn more complex textiles processes:

Pam: Seeing the textiles go through all the processes we talked about in textiles class was so great. It was fantastic; I loved how we got to see everything from start to finishing. I really liked that yarn spinning and dying the best. It would have been very useful to have taken textiles after this trip also, or have a more complicated textiles class after this trip.

Live, cool knowledge as competitive advantage. Students shared that their firsthand experience linking the knowledge from classroom to real-life situation would provide competitive advantages to their career. Susan clearly illustrated that not only was she able to relate her experience with knowledge, but she also was convinced that this live, cool knowledge would make her a better candidate in a job market. Mark confirmed that in his current internship:

Susan: We saw knitting machines and dyeing machines that I had only seen in my Textiles textbook before. It was a great experience to be able to link the knowledge that I have gained in class from books and lecture to this real life situation, and get a look at the real industry. I considered this to be the best of my experiences in El Salvador, and that by experiencing it I have an advantage over other people in both the industry and job market.

Mark: My study abroad trip to $\mathrm{El}$ Salvador was a great adventure and I would recommend it to anyone. Many of the things I have learned on that trip have helped me in my current internship.

\subsection{Transforming experience through reflective observation}

Reflection seemed to occur at any time. Some students were constantly going through the entire experiential learning cycle from gaining new experience to transforming the experience during the trip. Others seemed overwhelmed by new activities and experiences during the trip; they had more time for reflection only after they returned home. Some were happy to be at home where they feel safe and comfortable. Others were sad and even depressed to be back as they loved El Salvador very much. Regardless of when they reflected and how they felt to be back, two common themes emerged in reflecting experience: (1) guilt for all that I have; and (2) awareness of this whole other world:

Guilt for all that I have. Throughout the student journals, it was apparent that their experience in El Salvador provided a first, intense moment encountering a different culture in a third world country. While reflecting, students realized how much they have and have taken it for granted in their lives. This feeling was unanimously shared by all students although the level of feelings of guilt seemed to vary from one to another. In Laura's case, she started feeling guilty for all that she has from her personal belongings to health care and public safety. She finally realized that what education means to her:

Laura: I also experienced feelings of guilt for all that I have. I have more clothes than any one person could ever need, and have access to good health care, good healthy food, and a nice home and a bed to sleep in at night. Of all the things I learned from our trip to 
El Salvador, I learned how much my education means and how lucky I am to have these opportunities and the chance to be in college and to have made it this far in my education.

Beyond feeling guilty, Annie's spirituality was intensified; she even claimed now that it would be wasteful and sinful if she does not utilize everything she has.

Annie: I feel as if I have this vast amount of resources - a good education, financial stability, and a want to serve God through helping others. If I stay in the States I feel as if I am wasting all of this - there are people all over the world who need it so much more.

Awareness of this whole other world. It seemed that when students sat back and reflected on the whole experience, El Salvador did not seem real. Even if students were in a real world, El Salvador, and experienced real things, such as exploring new restaurants and bars, meeting and talking to local people, and walking through factories touching real materials and smelling distinctive odors, El Salvador became a 'whole other' world, as Mary put it, when all was done. Despite the close and intimate knowledge about El Salvador that they gained through this experience, by 'other world,' Mary found that she is now ready to move on to a real life at home in her world:

Mary: As we left the city of San Salvador on our bus, I reflected back on how much I had learned in my short week in the country. Throughout my time in El Salvador, I gained the realization of how a lot of the rest of the world lives. Although I have seen it on television, and read about it in books and magazines, you don't realize how other people live until you see it firsthand. Seeing the people, the houses they live in, and the way they spend their days opened my eyes completely to this whole other world.

\subsection{Transforming experience through active experimentation}

Throughout the trip, there was sufficient evidence that students learned something new, shared new knowledge, and tested it successfully for their incumbent needs. Because this experience was a one-time, unique event in students' learning, it was not possible to detect whether or not students actively tested, acted, and experimented with knowledge in a new situation in the long term. However, there were definite signs that some students started making long-term plans to utilize what they learned from this experience. Two themes that emerged in students' experimentation were: (1) trying new simple things; and (2) breaking out of the box.

Trying new simple things. Anita admitted that she is an over-packer. This problem was visible from the beginning of the trip. Her two large suitcases barely made it under the maximum weight allowance at the airport in the United States. Yet, she purchased more gifts and souvenirs in El Salvador; she confessed she was concerned about the weight of her luggage. Quickly, she learned how to pack efficiently, tried it, and successfully achieved what she needed. She was very proud of her new success:

Anita: I was very nervous about having to pay extra fees for my bag being overweight but somehow I managed to get my bag from 51 to 49 pounds. I learned the method of rolling your clothes to make more room in your suitcase! 
Sally also wanted to try to see what it is like to shop at the duty free shops at international airports. Although students were informed of duty free shops prior to departure, none of the students actually tried such stores. However, during the returning journey, at the San Salvador airport, many students indeed purchased products to try this new shopping experience, even if they did not need to shop:

Sally: I bought something at the Duty and Tax Free store so that I could see how that would be as an experience. I thought that you would just be able to take it with you after purchasing but instead they deliver it and give it to you right before you load the plane.

Breaking out of the box. While most students have experimented to satisfy immediate convenience or instant curiosity, a few students seemed to start taking steps to change their lives in the longer-term. Annie is senior who was not quite sure about her future and calling; yet, this experience, from the beginning to the end, seemed to fundamentally influence her life. She confessed that she would 'have to' make drastic life changes, suggesting the intensity of her urge to change. This change requires significant courage to step outside of her comfort zone and she recognized this very fact. She was one of the few students who appeared to touch all the basesexperiencing, reflecting, thinking, and acting:

Annie: El Salvador truly opened my eyes to the world, and made me realize that I have so much more to live for. I have been thinking a lot about what I am coming home to, and I realize that I am going to have to make some fairly drastic life changes. My values and beliefs have not completely changed, but many have been intensified -like my want to help others. I hope that one day
I am able to make a difference in the lives of people in Latin America whether it be through my service in teaching English, working in the Textile and Apparel industry, or perhaps even going as a missionary. When I received my Passport it included a piece of paper that said "The World is at Your Fingertips..." I want to explore that world, and not confine myself to what I have known and what is so comfortable.

\section{Conclusions}

An understanding of a global market environment is fundamental for today's students' career development, especially in the textile and apparel industry, the most globalized of all (Dicken, 2003). Thus, educators are expected to provide relevant knowledge and expose students to various facets of the globalized industry. Preparing students to be 'global-society ready' is clearly one of the most important missions of professional academic programs such as textile and apparel management (Fair et al., 1990). To be more effective in teaching international components, many educators have emphasized the importance of international experiential learning through international internships, field trips, or study abroad programs (Frontczak, 1998; Festervand and Tillery, 2001; Gaiders and Andrews, 1990; Gosen and Washbush, 2004; Helms et al., 2003). Thanks to these studies, much information is now available on how to develop new experiential curricula and how to assess success in such programs; however, little is known about how experience is actually obtained and transformed by students to create new knowledge.

To respond to this gap, the study analyzed students' journals from a shortterm study aboard program to capture how students grasp, conceptualize, reflect on, and experiment with new experiences in a 
completely foreign learning space, using experiential learning theory as the study's theoretical framework (Kolb, 1084). The study findings suggested, first, in a predominantly non-white society, students described being pale, blond, and American feels like sticking out like a sore thumb. For the first time in their lives, they felt like a minority, and it was an embarrassing moment. In a foreign environment, which felt incomprehensible for most, chaos meant the lack of organization, which in turn students interpreted as danger to their safety. This finding is consistent with Myers, Hill, and Harwood's (2005) analysis from a cross-cultural study abroad program in Costa Rica. The authors reported that students were able to transform themselves by 'surviving' many new challenges including being part of a minority, the lack of reliable urban infrastructure services, and the interaction with different social groups and different value systems. Second, students seemed to easily conceptualize what they learned in class throughout the program. Interestingly, however, students described that knowledge from class did not become alive and cool until they actually experienced it. Seeing, touching, smelling, and hearing what was in the textbooks was totally different from reading about it in class; students were convinced that this firsthand experience would provide additional competitive advantages over other students who had not traveled. Third, while reflecting on the whole experience, the economic, environmental, and societal differences between home and 'the other world' became clear; students expressed overwhelming guilt and, thus, more appreciation for all that they have at home. Finally, once experienced, experimenting with previous knowledge in a small scale for immediate needs seemed quite easy, harmless, and interesting for students. Long-term plans for experimentation on a large scale also emerged; some students were able to visualize themselves breaking out of the box where their lives were securely and comfortably contained.

This study makes several significant contributions and implications. First, the study elucidated the 'in-depth' understanding of the experiential learning process of textiles and apparel students whose career development is fundamentally dependent on their knowledge of global aspects of business activities. The in-depth descriptions differ from the findings of quantitative approaches in that they provide intimate, close descriptions of each learning mode as students grasp and transform their experiences. Thus, the study findings help educators gain a richer and more intimate understanding of students' experiences. Second, under an experiential learning theory framework, the study results clearly illustrated how students experience each of the four learning modes - experiencing, thinking, reflecting, and acting in a totally new learning space which was uncomfortable, incomprehensible, and foreign. Thus, the study offers an important implication to educators who wish to lead future study abroad or other experiential programs. Educators may be able to use these findings to better comprehend how students assess themselves and the new environment, which is unique for each learning mode. This close understanding, in turn, would help educators guide students to go through a complete cycle of experiential learning which is believe to be the most effective way of producing knowledge (Kolb, 1984).

Third, the study showed how knowledge from textbooks transforms into real, memorable knowledge to students in international experiential learning. Educators may want to find more effective ways to make global components of curriculum more interesting and meaningful 
for students, especially given that a large portion of business activities are in fact happening in foreign countries from manufacturing, supply chain management, to consumer research. Finally, the study findings illuminated students' unique feelings of embarrassment as well as guilt as U.S. Americans. It cannot be known in the scope of this study whether or not these feelings of embarrassment and guilt are universal to all students in other study abroad programs. The study results, however, provide important and interesting insights into how today's young U.S. Americans are currently shaping and building an image of U.S. American in a global marketplace.

Broad application of the interpretation presented here should be done with caution due to its basis on a one-time event of a short-term study abroad program. With this caution in mind, this study offers several important future research opportunities. First, further study is needed to apply findings to a larger population or different formats or length of study abroad programs. It is expected that experiential learning programs with a larger group of students would cause different dynamics among the student group, resulting in different learning experiences. The study's program was small and fairly homogeneous in students' demographics so that there was no apparent conflict among students. Too, the study results would have been different if the program lasted longer than a week or had a different number of visitations with companies or assignments every day. As learning occurs differently in different situation, more studies of the topic in different situations would help gain a deeper understanding of students' learning experience. Second, it might be interesting to investigate the origin of embarrassment as a U.S. American. This could help elucidate the image of U.S. Americans in foreign countries. Third, it is also useful to examine the role of 'guilt for all that they have' in the overall performance and productivity in students' college lives. If the feelings of guilt indeed improve students' academic performance, parents might want to consider encouraging study aboard programs throughout students' education. Finally, it would be fruitful to investigate the impact of international experiential learning throughout the life-time span. An understanding of how this experience helps students' careers throughout their lives would make a fundamental contribution to the pedagogy literature.

\section{References}

Bronfrenbrenner, U., 1979. The ecology of human development. Cambridge, MA: Harvard University Press.

Business Wire, 2007. Hanesbrands Inc. acquires textile plant in El Salvador capping successful first year as an independent company. Available from http://findarticles.com/p/articles/mi_m0 EIN/is_2007_Sept_6/ai_n27365402 [Accessed 17 July 2008]

Coleman, J., 1976. Differences between experiential and classroom learning. In: M. Keeton, ed. Experiential learning: Rationale, characteristics and assessment. San Francisco: Jossey-Bass, 49-61.

Chapman, S., McPhee, P. and Proudman, B., 1995. What is experiential education? In: K. Warren, M. Sakofs and J. Hunt, Kendall-Hunt, eds. The theory of experiential education. Dubuque, Iowa: Kendall-Hunt Publishing company, 235247.

Denslow, L., 2006. World wise: What to know before you go. New York: Fairchild.

Dicken, P., 2003. Global shift: Reshaping the global economic map in the $21^{\text {st }}$ 
century. $4^{\text {th }}$ ed. New York: The Guilford press.

Dickerson, K.D., 1999. Textiles and apparel in the global economy. $3^{\text {rd }}$ ed. Upper Saddle River, NJ: Prentice Hall.

Dutton, J. E. and Dukerich, J.M., 1991. Keeping an eye on the mirror: Image and identity in organizational adaptation. Academy of Management Journal, 34(3), 517-554.

Fair, N.B., Hamilton, J.A., \& Norum, P.S., 1990. Textile knowledge for merchandising professionals: Significance for pedagogy in clothing and textiles. Clothing and Textiles Research Journal, 8(2), 29-37.

Festervand, T.A. and Tillery, K.R., 2001. Short-term study-abroad programs: A professional development tool for international business faculty. Journal of Education for Business, 77(2), 106-111.

Frontczak, N.T., 1998. A paradigm for the selection, use and development of experiential learning activities in marketing education. Marketing Education Review, 8(3), 25-33.

Gadamer, H.G., 1975. Truth and method. $2^{\text {nd }}$ rev. In: J.Weinsheimer and D.G. Marshall, eds. \& trans. New York: Crossroad.

Gaidis, W.C. and Andrews, J.C., 1990. Management of experiential learning projects in marketing coursework. Journal of Marketing Education, 12(summer), 49-60.

Gosen, J. and Washbush, J., 2004. A review of scholarship on assessing experiential learning effectiveness. Simulation \& Gaming, 35(2), 270-293.

Ha-Brookshire, J. and Dyer, B., 2008. Apparel import intermediaries: The impact of a hyperdynamic environment on U.S. apparel firms. Clothing and Textiles Research Journal, 26(1), 66-90. DOI: $10.1177 / 0887302 X 07304479$
Helms, M.M., Mayo, D.T., and Baxter, J.T., 2003. Experiential learning: The benefits of trade shows for marketing students and faculty. Marketing Education Review, 13(3), 17-25.

Hultgren, F.H., 1989. Introduction to interpretive inquiry. In: F.H. Hultgren and D.L. Coomer, eds., Alternative modes of inquiry in home economics research, New York: State University of New York, 35-42.

Jennings-Rentenaar, T., Buckland, S.S., Leslie, C.A., and Mulne, S., 2008. Expanding opportunities in fashion merchandising: A successful internship programme through an innovative collaboration with the National NeedleArts Association. International Journal of Consumer Studies, 32, 323327.

Joplin, L., 1995. On defining experiential education. In: K. Warren, M. Sakofs and J. Hunt, Kendall-Hunt, eds. The theory of experiential education. Dubuque, Iowa: Kendall-Hunt Publishing company, 15-22.

Kadolph, S.J., 2005. Equipment experts: Enhancing student learning in textile science. Clothing and Textiles Research Journal, 23(4), 368-374.

Kolb, D.A., 1984. Experiential learning: Experience as the source of learning and development. New Jersey: Prentice-Hall.

Kolb, A.Y. and Kolb, D.A., 2005. Learning styles and learning spaces: Enhancing experiential learning in higher education. Academy of Management Learning and Education, 4(20) 193-212.

Kraft, R.J. and Kielsmeier, J., 1995. Experiential learning in schools and higher education. Dubuque, Iowa: Kendall-Hunt Publishing Company.

Kunz, G.I. and Garner, M.B., 2007. Going global: The textile and apparel industry. New York: Fairchild. 
Lave, J. and Wenger, E., 1991. Situated learning: Legitimate peripheral participation. Cambridge, UK: Cambridge University Press.

Marrow, A.J., 1977. The practical theorist: The life and work of Kurt Lewin. New York: Teachers College Press.

Mason, J., 1996. Sampling and selecting. In: J. Mason, ed. Qualitative Researching, London: Sage, 83-106.

Merriam, S., 1998. Conducting effective interviews. In: S. B. Merriam, ed., Qualitative research and case study applications in education. San Francisco: Jossey-Bass, 71-93.

Myers, D.N., Hill, M., and Harwood, S.A., 2005. Cross-cultural learning and study abroad: Transforming pedagogical outcomes. Landscape Journal, 24(2), 172-184.

Nelson, N., LaBat, K., and Williams, G., 2002. Contemporary Irish textile artists: Exploring experiences of gender, culture, and artistic medium. Clothing and Textiles Research Journal, 20(1), 15-25.

O'Hara, B.S. and Shaffer, T.R., 1995. Details and student perceptions of an experiential program for personal selling and purchasing classes. Journal of Marketing Education, 17(spring), 41-48.

Parilla, P.F. and Hesser, G.W., 1998. Internships and the sociological perspective: Applying principles of experiential learning. Teaching Sociology, 26(October), 310-329.

PROESA, 2008. Promoviendo la Inversión en El Salvador. Available from http://www.proesa.com.sv/ [Accessed 17 July 2008]

Sakofs, M., 1995. Piget-A psychological rationale for experiential education. In: K. Warren, M. Sakofs and J. Hunt, Kendall-Hunt, eds. The theory of experiential education. Dubuque, Iowa: Kendall-Hunt Publishing company, 149151.
Spiggle, S., 1994. Analysis and interpretation of qualitative data in consumer research. Journal of Consumer Research, 21(December), 491-503.

The World Factbook, 2008. El Salvador. Central Intelligent Agency. Available from

https://www.cia.gov/library/publications/ the-world-factbook/geos/es.html

[Accessed 10 July 2008]

Tchaicha, J.D. and Davis, M.M., 2005. The impact of culture on technology and business: An interdisciplinary experiential course paradigm. Journal of Management Education, 29(5), 738-757.

Toncar, MF. And Cudmore, B.V., 2000. The overseas internship experience. Journal of Marketing Education, 22(1), 54-63.

Thompson, C.J., 1997. Interpreting consumers: A hermeneutical framework for deriving marketing insights from the texts of consumers' consumption stories. Journal of Marketing Research, 34(4), 438-455.

van Manen, M., 1990. Turning to the nature of lived experience. In: M. van Manen, Researching lived experiences: Human science for an action sensitive pedagogy. New York: State University of New York, 35-46.

Warren, K., Sakofs, M. and Hunt, J., 1995. The theory of experiential education. Dubuque, Iowa: Kendall-Hunt Publishing company.

Wengraf, T., 2001. Qualitative Research Interviewing. London: Sage.

Wynd, W.R., 1989. An experiental approach to marketing education. Journal of Marketing Education, 11(summer), 6471. 
Table 1. Study Aboard in El Salvador Itinerary

\begin{tabular}{|c|c|c|}
\hline Date & Location & Activities \\
\hline May 19, 2008 & $\begin{array}{l}\text { St. Louis, Missouri, } \\
\text { U.S.A. }\end{array}$ & $\begin{array}{l}\text { - Flight to San Salvador was cancelled due to mechanical problems. } \\
\text { - Stayed overnight at St. Louis airport. }\end{array}$ \\
\hline May 20, 2008 & $\begin{array}{l}\text { San Salvador, } \\
\text { El Salvador }\end{array}$ & $\begin{array}{l}\text { - Met with PROESA, CAMPTEX, and Minster of Economics. } \\
\text { - Visited San Salvador Volcano. }\end{array}$ \\
\hline May 21, 2008 & $\begin{array}{l}\text { La Libertad, } \\
\text { El Salvador }\end{array}$ & $\begin{array}{l}\text { - } \quad \text { Visited Duraflex (Knitting factory). } \\
\text { - } \quad \text { Visited Partex (Apparel assembly factory). } \\
\text { - } \quad \text { Toured San Andres Ruins. }\end{array}$ \\
\hline May 22, 2008 & $\begin{array}{l}\text { San Salvador, } \\
\text { El Salvador }\end{array}$ & $\begin{array}{l}\text { - Visited Industrias St. Jacks (Local brand, vertical factory). } \\
\text { - } \quad \text { Visited San Salvador Military Museum. } \\
\text { - } \quad \text { Walking tour downtown San Salvador. }\end{array}$ \\
\hline May 23, 2008 & $\begin{array}{l}\text { La Libertad, } \\
\text { El Salvador }\end{array}$ & $\begin{array}{l}\text { - Visited local fish market. } \\
\text { - Toured Beaches. }\end{array}$ \\
\hline May 24, 2008 & $\begin{array}{l}\text { San Salvador \& } \\
\text { Suchitoto, } \\
\text { El Salvador }\end{array}$ & $\begin{array}{l}\text { - Visited department stores and two upscale shopping malls. } \\
\text { - Toured Suchitoto (historic town) and ride boats. }\end{array}$ \\
\hline May 25, 2008 & $\begin{array}{l}\text { San Salvador, } \\
\text { El Salvador \& } \\
\text { St. Louis, Missouri, } \\
\text { U.S.A. }\end{array}$ & $\begin{array}{l}\text { - Shopped at Duty Free Shops at San Salvador airport. } \\
\text { - Returned home. }\end{array}$ \\
\hline
\end{tabular}




\section{Table 2. Participating Students' Demographic Information}

\begin{tabular}{|c|c|c|c|c|c|}
\hline $\begin{array}{l}\text { Participating } \\
\text { Students }^{1}\end{array}$ & Age & Gender & Academic Level & $\begin{array}{c}\text { Overall } \\
\text { GPA }\end{array}$ & $\begin{array}{l}\text { International } \\
\text { Trip Experience }\end{array}$ \\
\hline Mary & 21 & Female & Senior & 3.8 & None \\
\hline Cheri & 21 & Female & Senior & 3.2 & None \\
\hline Jan & 23 & Female & Senior & 2.8 & None \\
\hline Sally & 21 & Female & Junior & 3.1 & None \\
\hline Jean & 20 & Female & Sophomore & 3.6 & None \\
\hline Anita & 21 & Female & Sophomore & 2.8 & None \\
\hline Barbara & 21 & Female & Junior & 2.5 & Once, Mexico \\
\hline Chris & 19 & Female & Sophomore & Unsure & None \\
\hline Kris & 23 & Female & Senior & Unsure & None \\
\hline Annie & 22 & Female & Senior & 3.0 & None \\
\hline June & 21 & Female & Senior & 3.1 & None \\
\hline Pam & 20 & Female & Sophomore & 3.2 & None \\
\hline Laura & 21 & Female & Junior & 2.4 & None \\
\hline Amy & 19 & Female & Sophomore & 2.8 & $\begin{array}{l}\text { Once, The } \\
\text { Bahamas }\end{array}$ \\
\hline Brooke & 35 & Female & Doctoral student & 4.0 & Born in Barbados \\
\hline Mark & 21 & Male & Junior & 2.4 & None \\
\hline Susan & 20 & Female & Sophomore & 3.85 & None \\
\hline Kathy & 22 & Female & Senior & 2.8 & $\begin{array}{l}\text { Once, Western } \\
\text { Europe }\end{array}$ \\
\hline
\end{tabular}

Note. ${ }^{1}$ Reference to each participant is indicated by a pseudonym; ${ }^{2}$ Textile and Apparel Management 